\title{
An Analysis of the Jamaican Grades 1-6 Curriculum for the Development of a Media and Information Literacy and Intercultural Dialogue Cross-Curriculum
}

\author{
Dr. Paulette Stewart \\ University of the West Indies, Mona,Jamaica)
}

\begin{abstract}
The main objective of any curriculum is the relevancy of the content in meeting the curricular and cocurricular short and long term needs of the students so they can function well at their level in the society. The researcher used the content analysis methodology to analyse the content of the Grades 1-6 Ministry of Education Youth and Information (Jamaica) Curricular with the aim of developing a school library cross-curricular. Based on the analyses there was evidence that more information literacy topics were implicitly embedded in the school curriculum guides than media literacy and intercultural dialogue. The AASL Standards for the $21^{\text {st }}$ Century Learner competencies was either sufficiently evident, limited or absent from these school curricular. The cooperative learning teaching strategy, the multiple intelligences theory and the Big6 information problem solving skills were also absent from these curricular. The researcher used the subject areas in addition to the MILID components to develop a cross curricular school library MILID curriculum which will facilitate the collaboration of teacher librarians and teachers in the planning and delivery of the lessons.
\end{abstract}

Key words: School Library Cross-Curricular, Media and Information Literacy Curriculum, Intercultural Dialogue Curriculum, School Library Curriculum

\section{INTRODUCTION}

The main objective of any curriculum is the relevancy of the content in meeting the curricular and co-curricular short and long term needs of the students so they can function well at their level in the society. The Information Age has brought about a proliferation of media and information providers that everyone, including primary school students, uses to access and disseminate information. As a result the school and the library curriculum should include content that will teach students how to be media and information literate. This becomes necessary because there are challenges when evaluating the relevancy and the reliability of the information. The emergence of media tools that allow students to communicate across borders makes it critical for the teaching of intercultural dialogue. UNESCO has therefore recognized the need for students to acquire Media and Information Literacy and Intercultural Dialogue (MILID) competencies to effectively engage with media and information providers. UNESCO also notes that a Media and Information Literacy (MIL) Curriculum should be incorporated into the formal education system because according to Wilson (2012), "the capability allow citizens to engage with media and other information providers effectively, and develop critical thinking and life-long learning skills for socializing and becoming active citizens" (para. 2).

The paper looks at Taba's conceptual framework for developing a curriculum. Next, it emphasises curriculum development in general and examines the advantages of using a cross-curricular design. The paper then indicates the competencies that are to be embedded in any MILID curriculum and highlights two examples of cross-curricular teaching models. The research then details how the teacher librarian can use a school library cross-curriculum to collaborate with classroom teachers to deliver lessons to students in all grades. This is followed by a detailed description of the Ministry of Education, Youth and Information (MOEYI) Curriculum; the theories underlying the development of the new curriculum are outlined, as well as how the American Association for School Librarians (AASL) Standards for the 21st Century Learner can be used in the development of the MILID curriculum. The paper then describes the methodology used to determine the MILID competencies in the curriculum 
developed by the MOEYI and the conceptual framework that the researcher used to develop the MILID curriculum. The findings and the analysis are detailed and the research ends with a graphic depiction of what the MILID cross-curriculum looks like, as well as a sample lesson plan.

The objectives of this paper are therefore to:

1. Find out the number of focus questions in the grades 1-6 curricular;

2. Identify the number of MILID topics in the MOEYI grades 1-6 curricular;

3. Use the topics in the MOEYI grades 1-6 curricular and the MILID components to develop a MILID cross-curriculum for school libraries;

4. Use the AASL Standards for the 21st Century Learner, cooperative learning, multiple intelligences theories, and the Big6 information literacy problem-solving skills in the creation of the lessons in the library curriculum.

\section{Rationale and Significance}

At present, there is no Media and Information Literacy and Intercultural Dialogue Curriculum for primary school children in Jamaica. In this Information Age, such curriculum is needed to ensure that the knowledge, attitude and skills required are taught in a systematic manner so that these students can function effectively and efficiently in the media rich environment. The school libraries need an MILID curriculum that will be easily incorporated into the school's existing curricular. This will make it easier for the Ministry of Education, Youth and Information to use it in the primary schools.

This research is significant because, as Alvior (2015, para. 5) states, "the development of a curriculum is not only about the school, the learners and the teachers. It is also about the development of a society in general." Additionally, this research is worthwhile as the curriculum that will evolve will provide a flexible structure for teachers to follow and will include learning outcomes for students to become life-long learners. The curriculum designed will use the cooperative learning and the multiple intelligences teaching strategies that will prove effective to help fulfil the curriculum objective of the Ministry of Education Youth and Information that every child can learn every child must learn. In addition, the impact of a MILID curriculum on students' learning will allow them to display appropriate MILID behaviour, which is a pre-requisite for participating effectively in the information society.

\section{Conceptual Framework}

Emans' (1966) description of Taba's conceptual framework was used to guide this research. Taba states that this framework is "a way of organizing thinking about all matters that are important to curriculum development ...., identifying the elements of the curriculum, stating what their relationships are to each other, and indicating the principles of organization and the requirements of that organization for the administrative conditions under which it is to operate" (237).

\section{Curriculum Development}

\section{LITERATURE REVIEW}

Bilbao, Lucido and Iringan define curriculum development as a "planned, purposeful, progressive, and systematic process to create positive improvements in the educational system" (in Alvior, 2014, para. 2). They note that school curricula are affected whenever there are changes or developments around the world. As a result, there is a need to constantly re-design curricular to meet the academic and personal needs of students and for them to cope with the needs of the society. One such change that propelled the researcher to conduct this research that will lead to the development of a curriculum is the emergence of the Media and Information Literacy and Intercultural Dialogue concept.

The HMLe Improvement Scottish Education (2007, p. 4) notes that the number of schools adopting cross-curricular approaches to learning and teaching in a range of subject areas was on the increase. The report points out that the subjects commonly included in this type of instruction are aspects of English language, religious and moral education, drama, social subjects and personal, social and health education. The researcher will also take the cross-curricular 
approach to curriculum development as this can be implemented easily by teacher librarians collaborating with classroom teachers.

ConnectEd (2010) states that principals and teachers who have used the cross-curricular approach indicated that they have used it to move from a passive pedagogical approach to active teaching and learning where students were more engaged. There were also instances where students became the centre of learning by collaborating on real-life, career-focused projects and problems that were connected to their interests and future pursuits. The design also facilitated a teacher-directed rather than teacher-centred approach.

\section{Competencies Within a Curriculum}

Nikolov, Shoikova and Kovatcheva (2014, p. 4) state that researchers in the field of competence have proffered a number of definitions for the term competencies. These are: "permanent distinctive traits and characteristics which determine performance; distinctive characteristics which differentiate the successful performer from the rest; an ability to reach goals; inner personality traits that allow a person to cope better with a given task, role or situation; knowledge, skills, abilities and other characteristics demonstrated at work, etc." This definition shows that curriculum competencies consist of components that will lead students to acquire the requisite knowledge, skills and attitude.

These competencies are evident in information literacy and will enable students to "recognize when information is needed and have the ability to locate, evaluate and use effectively the needed information" (Association of College and Research Libraries [ACRL], 2000). Additionally, ACRL points out that the Leddy Library emphasizes the importance of critical thinking skills to information literacy which also means that an information literate individual has the ability to reflect critically upon and evaluate their own research strategies, the tools used, the resources found and the context in which the resources were produced. Media literacy will "empower citizens to understand the functions of media and other information providers, to critically evaluate their content, and to make informed decisions as users and producer of information and media content" UNESCO, n.d.). Intercultural dialogue competencies are necessary to prevent conflict as people communicate across culture. UNESCO in support of this states that because of technology, the world is more interconnected and so for individuals and societies to live together in harmony and in a safe world adequate wisdom is needed to prevent conflict" (UNESCO, n.d.).

\section{Designing a Cross-curricular Framework}

When designing a curriculum there are some key questions the planner needs to ask. Some of these are cited by Webber (2016) as: Does the curriculum include skills which prepare students for college and for the $21^{\text {st }}$ century workforce? Are teachers using the curriculum to guide decisions about instruction and assessment? What are the strengths of our curriculum? What are the weaknesses of our curriculum? These questions are pertinent because for teaching and learning to be successful there must be clarity about important learning outcomes and about the evidence that will show that learning has occurred (McTighe, 2010 in Webber, 2010).

ConnectEd (2010) highlights some important requirements for developing a cross-curricular. One requirement is that, there needs to be an agreement to implement a common curricular focus that will cut across disciplines. The research concurs with this requirement because it is ideal for teacher librarians. For example, teacher librarians need to work with all teachers of various subject disciplines to locate resources in the library and to collaborate in the teaching and learning process in order to make students' learning more meaningful. This type of teaching arrangement fits the other requirement, which is a flexible schedule that allows integrated, multidisciplinary project work and involvement with the world beyond school. The flexible timetabling of students to use the library is extremely important. It means that students will always get to use the library at the point of need. The teacher librarian will at this point provide the resources for their projects as well as teach them the research skills necessary to complete their project.

For this to be accomplished, the teacher librarian has to be aware of what is been taught in the classrooms, which supports the other requirement stated by ConnectEd (2010), that of common planning time allotted for teachers, to formulate and coordinate the components of an integrated unit. During the 
common planning time, the teacher librarian will meet with the teachers, find out what they are planning to teach and use this knowledge to prepare resources that will meet both teachers' and students' information needs. It will also show the work that students need to do outside of their classroom setting. Therefore, when designing a cross-curricular activity, the teaching methodology section should indicate the role of the teacher and the role of the librarians and any other persons that will be involved in the preparation or delivery of the lessons. This shows the shared responsibility involved in the delivery of a lesson within a cross-curriculum.

\section{Cross-curricular Teaching Model}

In describing the cross-curricular teaching model, Barnes (2104) opens chapter 14 of the book, An Introduction to Cross-curricular Learning, with this colourful statement:

The world beyond the classroom is cross-curricular. Through my window I see walls, trees, people walking by, cars, birds, clouds and the occasional aeroplane - I understand none of them fully from the perspective of just one curriculum subject. I describe and appreciate the cherry tree outside using a combination of geographical, artistic, poetic, philosophical and historical vocabularies. Others might perceive the same scene by linking thoughts from mathematics, science, design, music, movement or religious education. We each look on the world, its objects, patterns and experiences, with different eyes. (pp. 260-261).

This gives a vivid picture that a cross-curricular framework contains an overlapping of pedagogy and the connection of subject elements which offer the opportunity to integrate and structure these separate learning experiences that can make teaching and learning more meaningful. A MILID cross-curriculum will show the collaboration between the teacher librarian and classroom teachers engaging students in the delivery of MILID lessons that are derived from the various subject areas in the Grades 1-6 curricular. The following shows two samples of cross-curricular teaching and learning in which the subject borders are exceeded and other subjects are integrated.

Figure 1. Sample of Cross-curricular Teaching - Mathematics and Sports
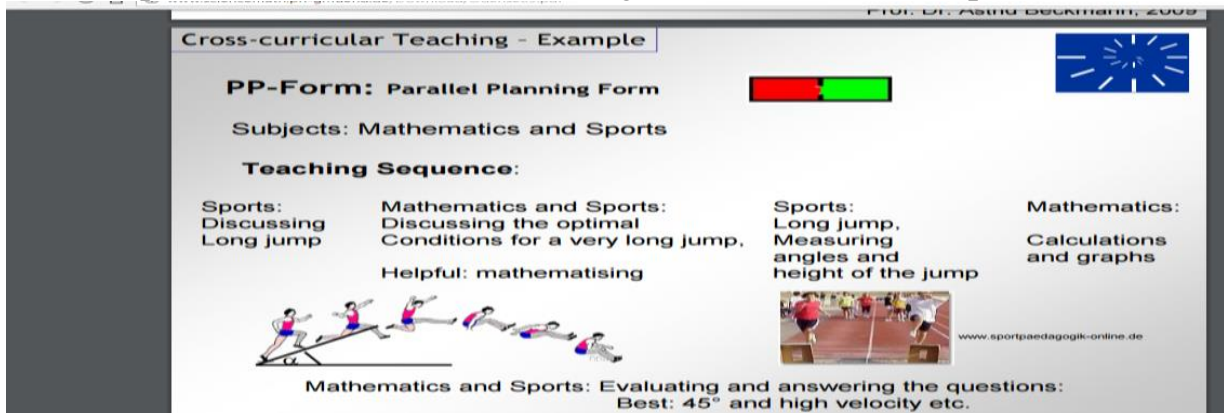

Source: http://www.sciencemath.ph-gmuend.de/Download/Odense09.pdf

Figure 2. Sample of Cross-curricular Teaching - Mathematics and Biology

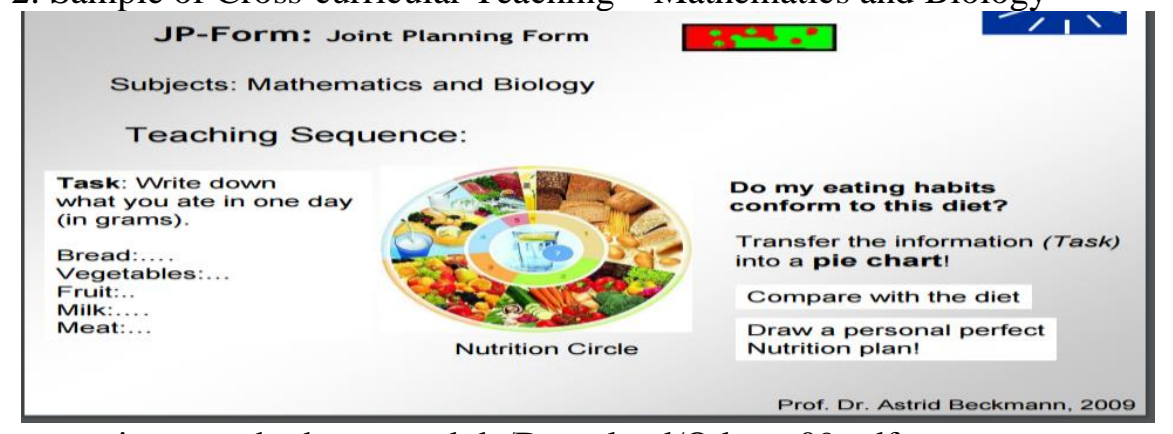

Source: http://www.sciencemath.ph-gmuend.de/Download/Odense09.pdf

\section{The Teacher Librarian and the Cross-curricular}

The teacher librarian is said to be one of the most important individuals in any school system and the library is the heart of the school. This notion stems from the fact that the teacher librarian is the link that connects students and faculty to the sources they need to meet their information needs. The pivotal 
role that librarians perform in school involves collaborating with teachers of any subject area to teach MILID topics, thus achieving the cross-curricular approach to teaching and learning. For example, in cooperation with the teacher who is teaching how to interpret pictorial data in Mathematics, the librarian can teach a lesson on visual literacy. Likewise, a lesson on relating to others outside of Jamaica can be used by the librarian to teach about intercultural dialogue.

\section{What Does the MOEYI Curriculum Look Like? Background information}

In 1999, the then Ministry of Education Youth and Culture re-designed the Grades 1-6 primary school curricular. The re-design was due to the response to the demand from teachers, teacher trainers, parents, educators and other stakeholders. They advised that the revised curricular should "be based on the needs of the child and the society not on the requirement of a particular subject, the focus should be on learning rather than teaching; give children the opportunity to work together and discuss their work; recognize that there are different ways of being intelligent and provide opportunities for the development of all the intelligences; and children need to be educated about many social cultural and health issues. The curriculum should cater to these needs" (MOE, viii). According to Bowie (1999, iii) this interest group made a strong suggestion that concepts such as healthy lifestyle, Garveyism, tourism environmental awareness and the role of aesthetics in personal development be included in the curriculum.

\section{Curriculum Framework}

\section{Grades 1-3 - cross-curricular approach}

The grades 1-3 curricular were re-designed using the cross-curricular approach. The crosscurricular approach is defined as an approach to a topic that includes contributions from several different disciplines and viewpoints (Free Dictionary). This means that links are established between subject areas to make learning more meaningful. Critical to the development of this type of curriculum is the MOEYI mantra that every child can learn, every child must learn. This can be achieved, as the Ministry of Education in British Colombia states that a cross-curricular should lead to the development of the whole child - intellectually, personally and socially.

Additionally, this ministry asserts that cross-curricular competencies are the set of intellectual, personal, and social skills that all students need to develop in order to engage in deeper learninglearning that encourages students to look at things from different perspectives, to see the relationships between what they are learning in different subjects, and to make connections to their previous learning and their own experiences as members of their families, communities and the larger society (3). The content of the MOEYI curricular are therefore integrated and organized around specific major themes to facilitate greater meaning to learning. This is supported by effective methodologies, learning experiences and assessments (Barrett, 1999). These curricular illustrate the integration of content around major themes, the overarching theme being "All about Me and My Environment." This approach adds greater meaning to learning and is supported by effective methodologies, learning experiences and assessments. Special time slots referred to as 'windows' are used to focus on the development of literacy and numeracy skills, which represents the emphases placed on this curriculum. The units are preceded by an overview of the themes, sub-themes and topics. Figure 3 shows the scope and sequence of these curricular.

Figure 3: Scope and Sequence of the Grades 1-3 Curricular 
SCOPE AND SEQUENCE GRADES 1-3

\begin{tabular}{|c|c|c|c|c|}
\hline & GRADE 1 & GRAD̄E 2 & GRADE 3 & \multirow{3}{*}{ TERM } \\
\hline THEME & \multicolumn{3}{|c|}{ ALL ABOUT ME AND MY ENVIRONMENT } & \\
\hline SUB-THEME & $\mathbf{M}$ & $\mathbf{E}$ & $\mathbf{L}$ & \\
\hline Unit 1 & - Who Am I? & - My Body (Part II) & - My Body (Part III) & \\
\hline Unit 2 & - My Body (Part I) & - Care and Safety of Self & - Satisfying Other Needs & 1 \\
\hline SUB-THEME & MY HOME & MY FAMILY & $\begin{array}{l}\text { MY COMMUNITY, THE } \\
\text { NATION AND THE WIDER } \\
\text { WORLD }\end{array}$ & \\
\hline Unit 1 & - My Family & $\begin{array}{l}\text { - Living Together as a } \\
\text { Fanily }\end{array}$ & $\begin{array}{l}\text { - Providers of Goods and } \\
\text { Services }\end{array}$ & \\
\hline Unit 2 & - Things in the Home & - Satisfying Our Needs & $\begin{array}{l}\text { - Relating to Others Outside of } \\
\text { Jamaica }\end{array}$ & 2 \\
\hline Unit 3 & & & $\begin{array}{l}\text { - Aspects of the Jamaican } \\
\text { Culture }\end{array}$ & \\
\hline SUB-THEME & MY SCHOOL & MY COMMUNITY & $\begin{array}{c}\text { MY PHYSICAL } \\
\text { ENVIRONMENT } \\
\end{array}$ & \\
\hline Unit 1 & - Myself at School & - This is My Community & $\begin{array}{l}\text { - Living and Non-living Things in } \\
\text { My Environment }\end{array}$ & \\
\hline Unit 2 & - Together at School & $\begin{array}{l}\text { - Places of Interest in My } \\
\text { Community }\end{array}$ & - Caring for My Environment & 3 \\
\hline Unit 3 & 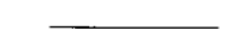 & $\begin{array}{l}\text { - Plants and Animals in My } \\
\text { Community }\end{array}$ & 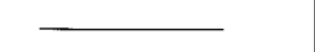 & \\
\hline
\end{tabular}

Source: MOE Curriculum, 1999, p. xv

\section{Research Findings in the Use of Cross-curricular}

Price (2010) conducted research commissioned by the National Teacher Research Panel on the benefit for teaching and learning of cross-curricular work in 2010. A number of findings emerged. These were: there was an improvement in the quality of numerous areas of pupil learning, including: questioning, self and group reflection, sharing of ideas, consensus and awareness of task requirements. Some students (from across the attainment range) became increasingly aware of the 'thinking skills' they were using. A minority became confident at transferring their use into different contexts. There was a general rise in confidence amongst the students in tackling tasks, making suggestions and criticising assumptions. Teachers also noted that effective collaboration was more apparent when students had time dedicated to thinking skills (p.1).

\section{Grades 4-6 Curricular}

\section{Conventional discrete subject organization approach}

The conventional discrete subject organization approach of the grades 4-6 curricular were retained when the primary school curriculum was re-designed. Phyllis (1999) mentions that although this is a discrete curriculum there are opportunities for integration through research and projects based on interdisciplinary themes. Additionally, Barrett (1999) pointed out that there is a greater linking of the content within and between topics to ensure coherence. A good feature of these curricular is that they are flexible so that teachers can adapt them to facilitate the varying learning styles and academic abilities. The Grades 4-6 curricular represent the discrete disciplines - drama, language arts, mathematics, music, physical education, religious education, science, social studies and visual arts with thematic integration being encouraged across subjects by the use of projects and group work. Technology is infused in all the unit. Each of these curricular has three strands that stretch across the curricular for the three terms. These are: creating, expressing, appreciating and evaluating. An example of the strands and how they are distributed across grades, subjects and terms is shown in Figure 4.

Figure 4: An Example of the Three Strands and Topics in the Grades 4-6 Curriculum 
classroom. They have produced a plethora of new information that has implications for how children learn and how teachers teach. The work of researchers includes evidence that educators can use students' strong intelligences to strengthen the weaker intelligences. Therefore, this theory is suitable for Jamaican students who have varying levels of academic abilities. Another implication is that using multiple intelligences as a teaching strategy provides students with multiple ways to demonstrate knowledge and skills, increases engagement and learning and provides teachers with more accurate understanding of students' knowledge and competencies (Darling-Hammond, 2010).

\section{Cooperative Learning}

Reynolds (1999) mentions the use of cooperative learning theory, which will offer students opportunities to be engaged in group and project work. It is the researcher's belief that this is an appropriate theory within which to design this curriculum as the cooperative teaching strategy can allow students of all academic levels to experience success. Extensive meta-analyses across hundreds of research on the effects of cooperative learning on students' academic achievement confirm that students who are taught using this method have higher levels of reason, more frequent generation of new ideas and solutions, significantly higher test scores and deeper understanding of the material (Johnson \& Johnson, 1989, Slavin, 1991, Herreid, 1998, Lord, 2001, Springer et al., 1999, Barkley, et al., 2005). All this is accomplished through the five elements of cooperative learning - positive interdependence, individual and group accountability, interpersonal and small group skills, face-to-face promotive interactive and group processing.

\section{The Big 6 Skills Information Literacy Skills}

The Big6 guide to information problem solving has six stages. These are task definition, information-seeking strategies, locate and access, use of information, synthesis and evaluation, which form the core elements of information literacy. The Big6 Skills are applicable to all subject areas at all grade levels to teach students how to solve problems, make decisions or complete specific tasks (Eisenberg \& Berkowitz, 2017). The steps in the Big6 Information Literacy Skills should help students to complete their assignments successfully and to evaluate the tasks completed in terms of production and

\section{Standards for the $21^{\text {st }}$ Century Learners} the process used to complete the product.

When developing a school library curriculum the Standards for the $21^{\text {st }}$ Century Learner should be included as they offer vision for teaching and learning to guide our professionals as educational leaders. In the school library context, the Standards will both shape the library program and serve as a tool to help teacher librarians craft the learning of students in the school (AASL, n.d.). Another rationale for including the AASL Standards in the curricular is that standards establish the levels of performance that students, teachers and schools are expected to meet and while they typically define es sential academic content knowledge, they should also define the competencies that contribute to success in modern life, such as life skills, learning and innovation skills, and information, media and technology skills (Partnership for the $21^{\text {st }}$ Century Skills, p. 3). AASL summarizes the Standards into four main areas: inquire, think critically and gain knowledge; draw conclusions, make informed decisions, apply knowledge to new situations, share knowledge and participate ethically and productively as members of our democratic society and pursue personal and aesthetic growth. Subsumed under each area is skills, disposition in action, responsibilities and self-assessment strategies.

AASL (2007) gives an overview of these critical standards. In the area of skills and disposition in action, reading is seen as the fundamental skill for learning, personal growth and enjoyment. This area also includes the degree to which students can read and understand text in all its formats and context as a key indicator of success in school and life. The inquiry component of this area provides a framework for learning. It is mentioned by AASL (2007) that for students to become independent learners they must not only gain the skills but also the disposition to use those skills along with an understanding of their own responsibilities and self-assessment strategies. These elements combined can build a learner who can thrive in a complex information environment (p. 2). 
The key terms and their descriptions used in these curricular are shown in Table 1.

Table 1 - Key Components and their Description in the MOE Curriculum

\begin{tabular}{|l|l|}
\hline Components & Description \\
\hline Attainment target & $\begin{array}{l}\text { Describes what pupils of different abilities and maturity levels should all understand } \\
\text { and show by their behaviour that they value at the end of each level. }\end{array}$ \\
\hline The objective & $\begin{array}{l}\text { Indicates in measurable terms what pupils should be able to do in relation to } \\
\text { specific lessons or sets of lessons. They are derived from the attainment targets and } \\
\text { reflect what is to be achieved. }\end{array}$ \\
\hline The focus question & $\begin{array}{l}\text { Serves to define the scope and sequence of the unit. It gives structure and focus to } \\
\text { the unit by ensuring that the essential concepts within the topics are addressed. }\end{array}$ \\
\hline Key vocabulary or & $\begin{array}{l}\text { Are those essential and pivotal terms introduced during the course of the unit? They } \\
\text { will become (if they were not before) part of the pupils' active vocabulary. }\end{array}$ \\
\hline $\begin{array}{l}\text { The procedure/ } \\
\text { activities }\end{array}$ & $\begin{array}{l}\text { Present the actual experiences in which the pupils will engage in order to achieve } \\
\text { the stated objectives. }\end{array}$ \\
\hline The skills & $\begin{array}{l}\text { Indicate what distinctly and specifically the pupils will be able to do during the } \\
\text { course of the unit. They indicate the dexterities and abilities the pupils are in the } \\
\text { process of acquiring and are expressed as verbs in the continuous tense. }\end{array}$ \\
\hline Assessment & $\begin{array}{l}\text { Is there evidence of learning, that is, process development, conceptual insight and } \\
\text { knowledge? Assessment tasks result in a tangible product, an observable } \\
\text { performance or a combination of both. }\end{array}$ \\
\hline Evaluation & $\begin{array}{l}\text { Provides the criteria to guide the teacher in determining the level of performance by } \\
\text { the pupils, that is, for assessing the products or performance presented. }\end{array}$ \\
\hline
\end{tabular}

Source: MOE Curriculum, 1999, p. x

\section{Theories should Guide the Development and Delivery of the School Library Curricular Multiple intelligences}

Reynolds (1999) points out that the Grades 1-6 curricular are designed on the premise that every child can learn, and this is why the curriculum is designed to identify and develop all the multiple intelligences as theorized by neuropsychology and development expert Howard Gardner. After Gardner reviewed the traditional intelligences he conjectured that any individual has a variety of intelligences and briefly describes them as:

- Verbal-linguistic intelligence - well-developed verbal skills

- Logical-mathematical intelligence - ability to think conceptually, abstractly and discern logical and numerical patterns

- Spatial-visual intelligence - capacity to think in images and pictures, to visualize accurately and abstractly

- Bodily-kinaesthetic intelligence - ability to control one's body movements and to handle objects skilfully

- Musical intelligences - ability to produce and appreciate rhythm, pitch and timber

- Interpersonal intelligence - capacity to detect and respond appropriately to the moods

- Intrapersonal - capacity to be self-aware and in tune with inner feelings, values, beliefs

- Naturalist intelligence - ability to recognize and categorize plants, animals and other objects in nature

- Existential intelligence - sensitivity and capacity to tackle deep questions about human existence

Source: Thirteen Ed. Online, 2004

Howard Gardner (1983, 1993, 1999a, 1999b, 1999c, 2004, 2008, 2011) and other researchers (Caine \& Caine, 2001; Diamond \& Hopson, 1999; Jensen, 2005; Sylwester, 2004; Zadina, 2014, in Lunenburg \& Lunenburg, 2014, p. 1) in the area of brain research offer knowledge for application in the 


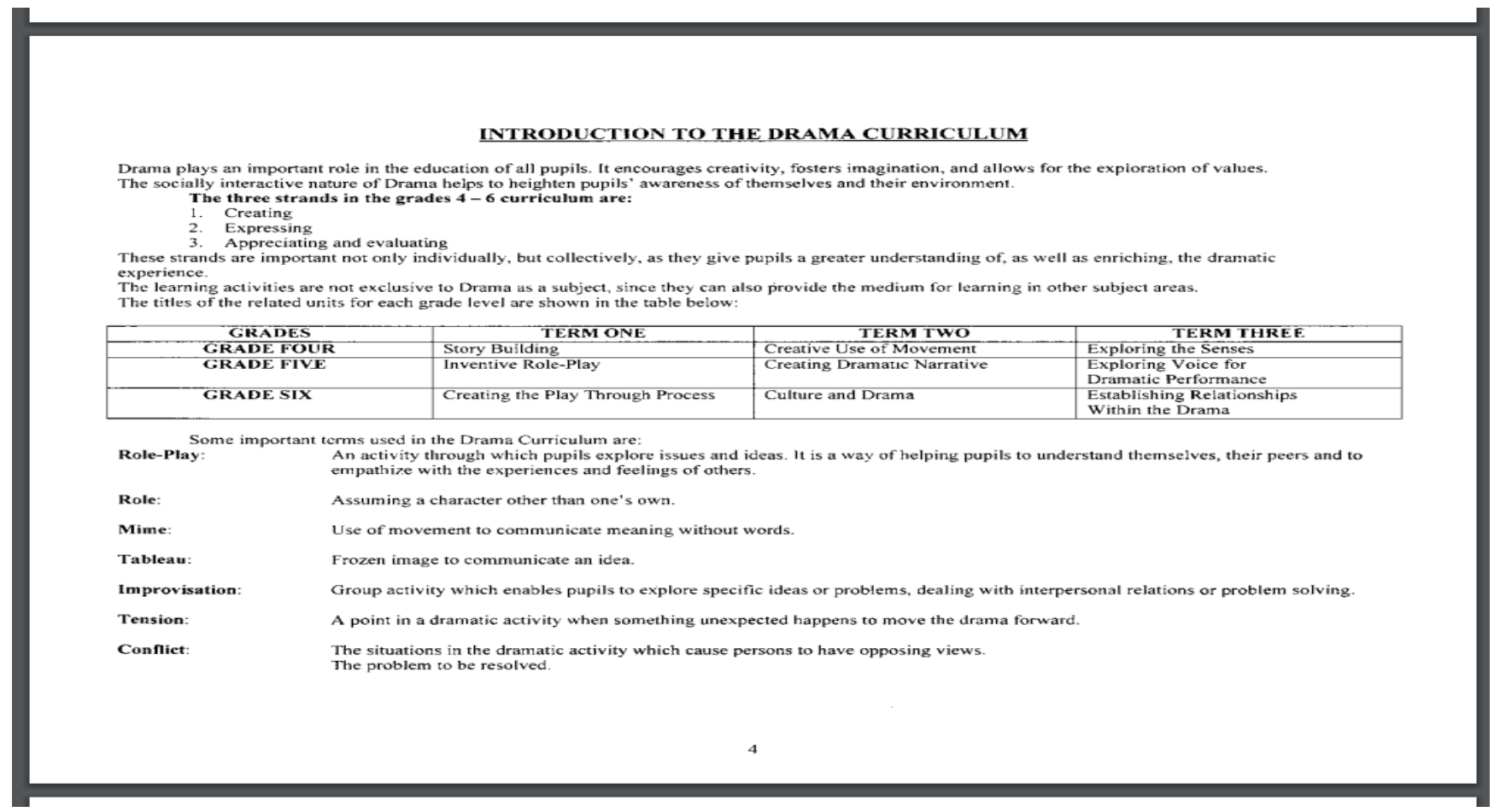

Source: MOE Curriculum, 1999, p. 4 
For the standard that covers responsibilities, AASL (2007) noted that as the world becomes more globalized, students must be taught to seek diverse perspectives and gather and use information and social tools ethically, responsibly and safely. Twenty-first century learners need to develop information skills that will enable them to use technology as a learning tool. All students deserve equitable access to information and information technology in an environment that is safe and conducive for learning (p. 2).

The self-assessment strategies address the multiple literacies such as digital, visual and technological which have joined information literacy as a crucial skill for this century. As a result of the proliferation of information available to our learners each student needs to acquire the skills to select, evaluate and use information appropriately. This standard also addresses learning, which has a social aspect because it provides the opportunity to share and learn with each other. Therefore, students need to develop skills in sharing knowledge and learning with others both in face-to-face situations and through technology. School libraries are made mention of here as they provide equitable access to resources and tools required for learning in an inviting, stimulating and safe environment. Of importance, school librarians collaborate with others to provide instruction, learning strategies and practice in using the essential learning skills needed for the $21^{\text {st }}$ century (p. 3). Table 2 shows an overview of the AASL (2007) critical standards for the $21^{\text {st }}$ century learner.

Table 2: The AASL Standards for the 21st Century Learner and Some of the Skills to be Taught

\begin{tabular}{|l|l|l|l|l|}
\hline $\begin{array}{l}\text { AASL Standards } \\
\text { for the 21 } \\
\text { Learner }\end{array}$ & Skentury & $\begin{array}{l}\text { Dispositions } \\
\text { in Action }\end{array}$ & Responsibilities & $\begin{array}{l}\text { Self-Assessment } \\
\text { Strategies }\end{array}$ \\
\hline $\begin{array}{l}\text { Inquire, think } \\
\text { critically and gain } \\
\text { knowledge. }\end{array}$ & $\begin{array}{l}\text { Find, evaluate and } \\
\text { select appropriate } \\
\text { sources to answer } \\
\text { questions. }\end{array}$ & $\begin{array}{l}\text { Demonstrate } \\
\text { creativity } \\
\text { by using multiple } \\
\text { resources and } \\
\text { formats. }\end{array}$ & $\begin{array}{l}\text { Respect copyright/ } \\
\text { intellectual property } \\
\text { rights of creators and } \\
\text { producers. }\end{array}$ & $\begin{array}{l}\text { Monitor gathered } \\
\text { information, and } \\
\text { assess for gaps or } \\
\text { weaknesses. }\end{array}$ \\
\hline $\begin{array}{l}\text { Draw conclusions, } \\
\text { make } \\
\text { informed decisions, } \\
\text { apply knowledge to } \\
\text { new situations and } \\
\text { create new } \\
\text { knowledge. }\end{array}$ & $\begin{array}{l}\text { Organize } \\
\text { knowledge so that it }\end{array}$ & $\begin{array}{l}\text { Demonstrate } \\
\text { is useful. } \\
\text { productivity by } \\
\text { completing products } \\
\text { to express learning. }\end{array}$ & $\begin{array}{l}\text { Use valid information } \\
\text { and reasoned } \\
\text { ethical decisions. }\end{array}$ & $\begin{array}{l}\text { Develop directions } \\
\text { for } \\
\text { future investigations. }\end{array}$ \\
\hline $\begin{array}{l}\text { Share knowledge and } \\
\text { participate ethically } \\
\text { and productively as } \\
\text { members of our } \\
\text { democratic society. }\end{array}$ & $\begin{array}{l}\text { Connect learning to } \\
\text { community issues. }\end{array}$ & $\begin{array}{l}\text { Demonstrate } \\
\text { teamwork by } \\
\text { working } \\
\text { productively with } \\
\text { others. }\end{array}$ & $\begin{array}{l}\text { Contribute to the } \\
\text { exchange of ideas } \\
\text { within and beyond } \\
\text { the learning } \\
\text { community. }\end{array}$ & $\begin{array}{l}\text { Assess the quality } \\
\text { and effectiveness of } \\
\text { the learning product. }\end{array}$ \\
\hline $\begin{array}{l}\text { Pursue personal and } \\
\text { aesthetic growth. }\end{array}$ & $\begin{array}{l}\text { Read, view, and } \\
\text { listen for pleasure } \\
\text { and personal } \\
\text { growth. }\end{array}$ & $\begin{array}{l}\text { Display curiosity by } \\
\text { pursuing interests } \\
\text { through multiple } \\
\text { resources. }\end{array}$ & $\begin{array}{l}\text { Recognize that } \\
\text { resources are created } \\
\text { for a variety of } \\
\text { purposes. }\end{array}$ & $\begin{array}{l}\text { Interpret new } \\
\text { information based } \\
\text { on cultural and social } \\
\text { context }\end{array}$ \\
\hline
\end{tabular}

\section{METHODOLOGY}

This is a qualitative research that collected data from the MOEYI grades 1-6 curricular through content analysis. Content analysis is defined as, "a research technique for making replicable and valid inferences from texts (or other meaningful matters) to the context of their use" (Krippendorf 2013, p. 24). Krippendorf also notes that this research technique "provides insight, increases a researcher's understanding of particular phenomena, or informs practical actions" (2013, p. 24). The data collection instrument was an observation checklist which was created based on the Council of Chief State School 
Officers' 2004 guideline for analysing curriculum content. The observation checklist was used to determine the subject areas that were recorded or implicit, the number of Focus Questions and the number of related MILID topics that were in the grades 1-6 curricular. The MILID topics were identified and labelled as ML, IL and ID.

The National Academy of Sciences (2004, p. 65) states, “An analysis of a curriculum's content should extend beyond a mere listing of content to include a comparison with a set of standards, other textual materials or other countries' approaches or standards." Therefore, the observation checklist included the description of the AASL Standards for the 21st-Century Learner and this was used to determine the presence of the AASL Standards in these curricular. Specific words and phrases such as inquire, critical thinking, draw conclusion were listed on the observation checklist and were ticked every time they were seen. These were totalled and described as sufficiently evident, limited or not seen. The data were collected over a period of one month and analysed. To support the analysis, the researcher engaged in triangulation by using quotes from the analysed text and literature (Krippendorf, 2013). The writing of the MILID curriculum took place over a period of four years using Taba curriculum conceptual framework and the theories mentioned in the literature review.

\section{Findings and Analyses}

The findings of the analysis of the grades 1-6 curricular show that there were subject areas that were clearly stated. These were, mathematics, religious education, physical education, technology, language arts, music, science, drama and visual arts. The ones that were implicit were media literacy, visual literacy, research literacy, library literacy, computer literacy, cultural literacy and storytelling. These are shown in Figure 5.

Figure 5: Subjects Identified in the Grades 1-6 Curricular

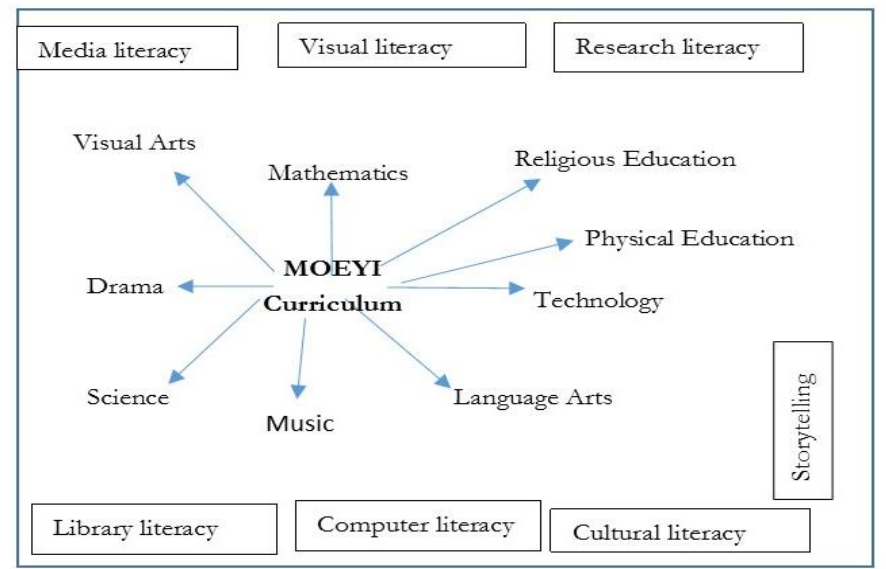

The first set of subject areas that were clearly stated represents the core subject areas of any primary school curriculum. However, due to the Information Age which is defined in the English Oxford Living Dictionary as, the era in which the retrieval, management, and transmission of information, especially by using computer technology, is a principal (commercial) activity. It therefore seems that these subject areas are inadequate to equip students with the necessary competencies to function effectively and efficiently in this type of society. The implicit subject areas that were identified fall within the MILID ecology and might have in some way provided students with some of these skills but in a very limited way. The number of these are shown in Table 3.

Table 3: The Number of Focus Questions and Implicit MILID Topics Identified in the Grades 1-6 curricular 


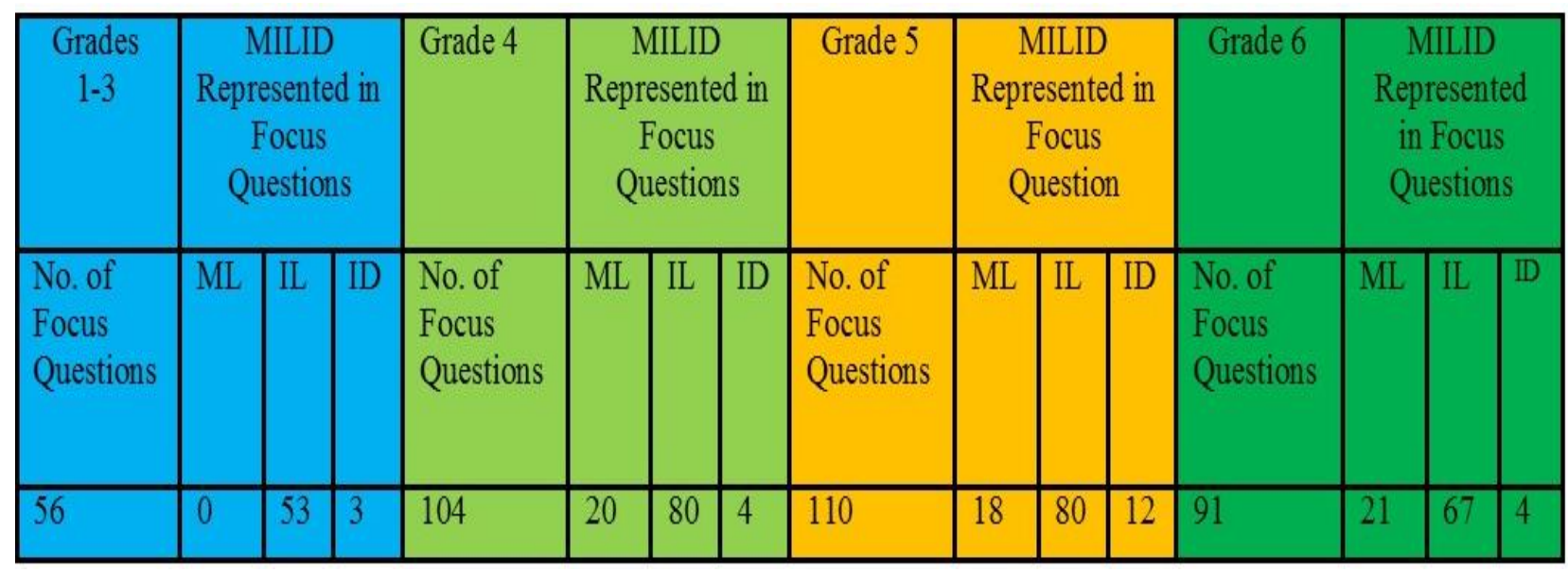

It was discovered that there were 56 focus questions in the Grades 1-3 curricular. In analysing the content of these curricular, it was discovered that $94.6 \%$ (53) of these focus questions could generate IL lessons and $5.4 \%$ (3) ID lessons. Of note is that no clear-cut or discrete ML literacy competencies were represented in the focus questions. The Grade 4 curriculum had 104 focus questions of which $77 \%$ (80) could produce IL lessons, $19.2 \%$ (18) could yield ML lessons and 3.8\% (4) could be used to create ID lessons. The Grade 5 curriculum had 110 focus questions. Seventy-three percent (80) of them could be used to create IL lessons and 16\% (18) ML lessons. Twelve (11\%) could generate lessons on ID. The Grade 6 curriculum had 91 focus questions of which 74\% (67) could be used to generate IL lessons while $21.6 \%$ (21) could be used to develop ML lessons. Only a mere $4.4 \%$ (4) could produce ID lessons.

This data indicate that in all six curricular there were a high percentage of IL lessons followed by ML and at all times a low representation of ID. The evidence of the implicit MILID topics seems to indicate that students who were exposed to these curricular were unknowingly taught some information literacy skills such as parts of a book and locating information from the content page, index and on maps. Media literacy competencies such as designing posters, communicating through graphic and other forms and interpreting graphic materials were also likely to have been discreetly taught under different subject areas. The ID lessons could have been embedded in lessons such as who are our Caribbean neighbours, how do I express and respond to music of our fore-parents and how do I express and respond to religious customs of peoples of different races? It is likely that since students were not exposed to this full cadre of MILID topics they would not have been fully equipped with MILID skills, knowledge and attitude.

\section{AASL Standards for the 21st Century Learner Identified in the Grades 1-6 Curriculum}

The researcher looked through the curriculum guides to see if there was evidence of the AASL Standards for the $21^{\text {st }}$ Century as these standards provide the framework for which students should learn the essential skills for success in today's world, such as critical thinking, problem solving, communication and collaboration. Table 4 indicates what was gleaned.

Table 4: Evidence of AASL Standards for the $21^{\text {st }}$ Century Learner in Grades 1-6 Curriculum

\begin{tabular}{|c|c|c|c|c|}
\hline $\begin{array}{l}\text { AASL Standards for the } 21^{\text {st }} \text { Century } \\
\text { Learner }\end{array}$ & Grades 1-3 & Grade 4 & Grade 5 & Grade 6 \\
\hline $\begin{array}{l}\text { 1. SKILLS } \\
\text { Inquire, think critically and gain knowledge }\end{array}$ & $\begin{array}{l}60 \% \\
\text { Sufficiently } \\
\text { evident }\end{array}$ & $\begin{array}{l}60 \% \\
\text { Sufficiently } \\
\text { evident }\end{array}$ & $\begin{array}{l}60 \% \\
\text { Sufficiently } \\
\text { evident }\end{array}$ & $\begin{array}{l}60 \% \\
\text { Sufficiently } \\
\text { evident }\end{array}$ \\
\hline $\begin{array}{l}\text { 2. DISPOSITION IN ACTION } \\
\text { Draw conclusions, make informed decisions, } \\
\text { apply knowledge to new situations and create } \\
\text { new knowledge }\end{array}$ & $\begin{array}{l}10 \% \\
\text { Limited }\end{array}$ & $\begin{array}{l}10 \% \\
\text { Limited }\end{array}$ & $\begin{array}{l}10 \% \\
\text { Limited }\end{array}$ & $\begin{array}{l}10 \% \\
\text { Limited }\end{array}$ \\
\hline 3. RESPONSIBILITIES & $5 \%$ Limited & $5 \%$ & $8 \%$ & $10 \%$ \\
\hline
\end{tabular}




\begin{tabular}{|l|l|l|l|l|}
\hline $\begin{array}{l}\text { Share knowledge and participate ethically and } \\
\text { productively as members of our democratic } \\
\text { society }\end{array}$ & & Limited & Limited & Limited \\
\hline $\begin{array}{l}\text { 4.SELF-ASSESSMENT STRATEGIES } \\
\text { Pursue personal and aesthetic growth }\end{array}$ & $\begin{array}{l}0 \% \\
\text { Not seen }\end{array}$ & $\begin{array}{l}0 \% \\
\text { Not seen }\end{array}$ & $\begin{array}{l}0 \% \\
\text { Not seen }\end{array}$ & $\begin{array}{l}5 \% \\
\text { Limited }\end{array}$ \\
\hline
\end{tabular}

The information in Table 4 indicates that the students exposed to these curricular would likely not have attained a reasonable level of the AASL Standards. Therefore, students would not gain the requisite skills required to function at their best in this media- and information-rich environment. It is likely that in the area of disposition in action, students would not have benefitted fully from sharing knowledge because of the absence of cooperative learning groups which promote teamwork through the cooperative learning element of face-to-face interaction via activities such as think-pair-share and think-square-share. In addition, in the area of responsibilities, knowledge such as plagiarism and how to avoid plagiarism could have been overlooked. For self-assessment strategies, it can be deduced that students have received feedback from teachers but there were no activities to show that the same was received from peers. The group processing element of cooperative learning would have helped to achieve this Standard.

Based on the analysis it became necessary for a school library curriculum to be developed that focuses on the literacies in the MILID ecology while ensuring that these are fully integrated into the regular subjects taught in these schools. The researcher used the knowledge gained from the content analysis, the conceptual framework, the theories mentioned and the AASL Standards for the $21^{\text {st }}$ century learner to develop a school library curriculum guide from grades 1-6. This cross-curricular approach would not require any extra time for delivery as these subjects would be seamlessly woven into all subject areas. The conceptual framework is shown in Figure 6.

\section{The Development of an Integrated MILID Curriculum}

Figure 6: Conceptual Framework Used to Create MILID Curriculum

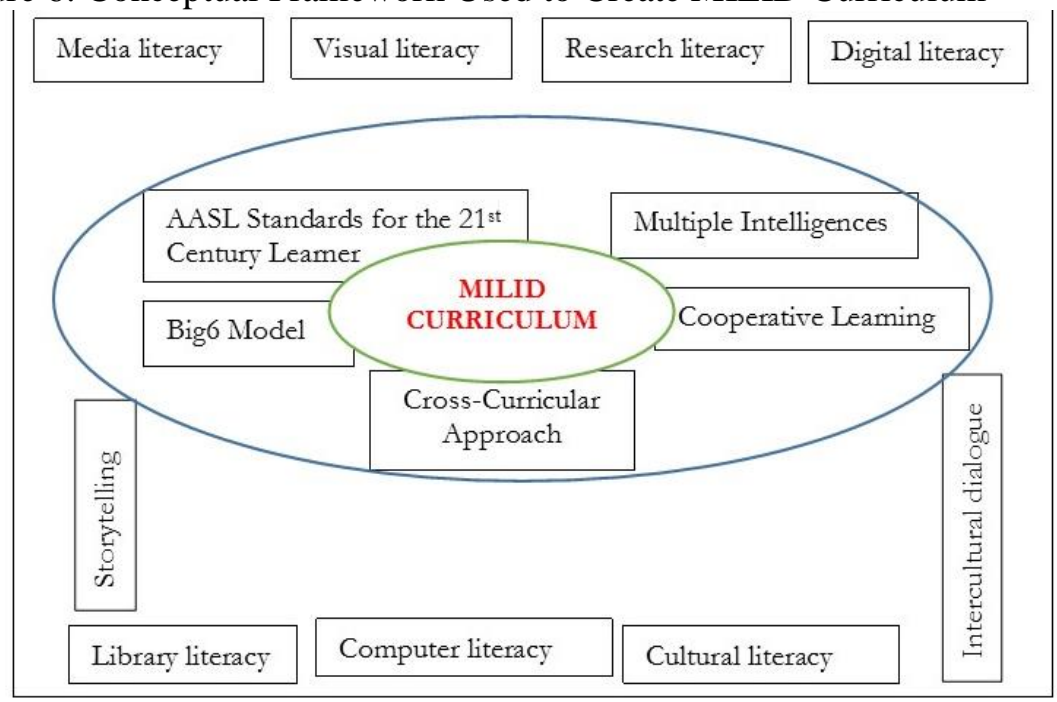

The conceptual framework shows the subject areas in the school library curriculum guide which are MILID related. These were used to create lessons related to the subject areas in the school grades 1-6 curricular, thus achieving the cross-curricular approach to teaching and learning. The lessons were created within the context of the theories of cooperative learning and multiple intelligences as well as the Big6 IL model. Each lesson also includes at least one of the AASL Standards for the $21^{\text {st }}$ century learner. The conceptual framework is shown in Figure 7. 
Figure 7: What the MILID Cross-curriculum Looks Like

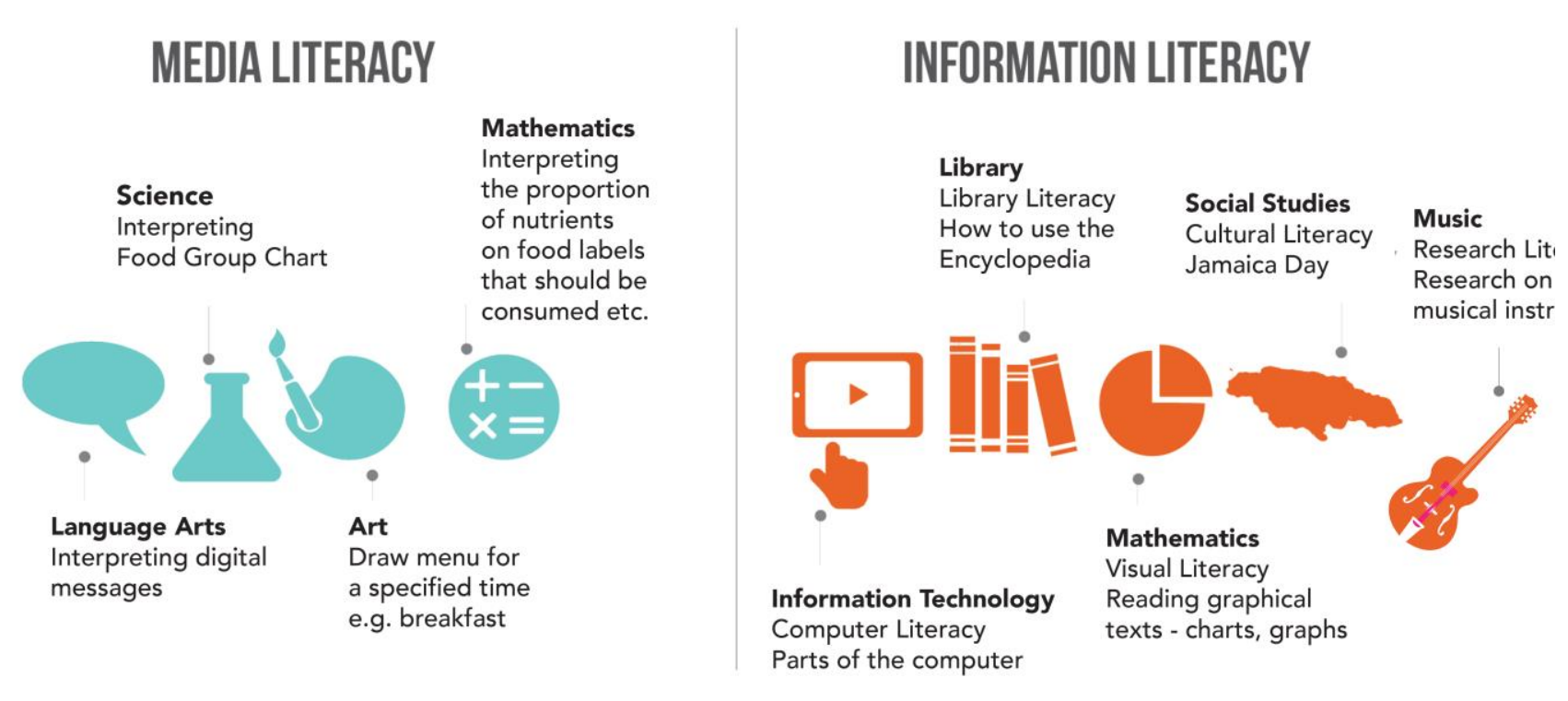

\section{INTER-CULTURAL DIALOGUE}
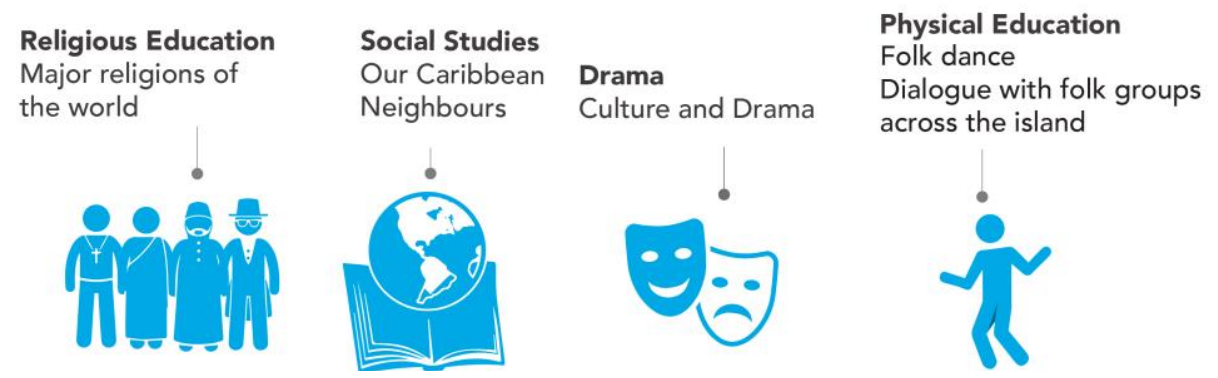

Figure 7 shows a sample of topics in the schools' curricular that could be used as entry points to deliver MILID school library cross-curricular. In the area of media literacy, subjects such as science, mathematics, language arts and art, the teacher librarian can collaborate with the classroom teacher to generate media literacy lessons to integrate with the lessons on food groups. For example, there is a media literacy lesson to help students interpret, analyse and evaluate information on a food group chart which they need to use to create a specific menu. The science lesson in the school curriculum that is based on interpreting food charts can integrated into a media literacy lesson to teach about ingredients on food labels and the proportion of nutrients that are good or bad for consumption as well as the advertising of food using digital technology to disguise the real appearance of what is actually sold.

Also in Figure 6, it is shown that information literacy can be integrated in a number of subject areas that were taught in the classroom. This is where the various types of literacy will be addressed such as the visual literacy that can be integrated with the mathematics lesson on reading graphical texts such as charts and graphs. With the emphasis now being placed on research in the primary schools in Jamaica, students' research skills can be enhanced under the area of information literacy; in this area the teacher librarian can help students with whatever content is been taught in class to define the information needed, determine the possible sources and select the best ones, locate sources and find the information within the 
sources, engage with the resources and extract the relevant information, organize the information from multiple sources in a coherent manner and finally evaluate the product in terms of effectiveness and efficiency (Big6). The proper use of the library and the use of information technology is also embedded in information literacy. These two are extremely important in the research process.

The phrase intercultural literacy is not now being used in the primary school curricular, but there are topics that can be used to integrate lessons to bring out the competencies and standards in this area. Religious education, social studies, drama and physical education as shown in Figure 6 are topics which can be seamlessly integrated into the intercultural lessons. In these subjects students can learn how to accept their culture and that of their Caribbean neighbours, recognize cultural and religious differences and deal with them harmoniously. Students are thus being trained to become good citizens as they use the knowledge gain from these lessons to communicate harmoniously and respectfully to everyone.

\section{Sample Lessons from the MILID Curriculum}

Topic:

School Library Curriculum: Types of Families

Grade 2: Living together as families

Attainment Target: For students to understand that families have different structures and

Lesson Outcomes compositions.

At the end of the lesson students should be able to:

1. Describe the different types of families from which students in selected classes belong;

2. Ask appropriate questions to find out the types of families in which students belong;

3. Create a simple bar graph to show the findings of their research on family types.

Information resources: Simple interview schedule, notebook, pencil

Skills: Interviewing, recording, reporting

AASL Standards for the $21^{\text {st }}$ Century Learner: Responsibilities - solicit and respect diverse

Teacher librarian and classroom teacher activities: perspectives while searching for information

1. Collaborate with classroom teacher to revise the types of families.

2. Teach social skills: Listening looks like/listening sounds like.

3. Engage: Guide students to describe their family structure and components.

4. Review: Step 1 and 2 of the Big6 information literacy skills - task definition and information seeking strategies.

5. Explain to students that they will be collecting information from students in other Grade 2 classes about the type of family in which they live. Help students to understand the task and how they will go about collecting the information.

6. Assist students in formulating the questions for the collection of data on family type, e.g.,

a. Who is the head of the household?

b. How many males and females are in your family?

7. Using examples, guide students on how to compare the size of the families using mathematical signs such as equal, greater than and less than, as well as comparative English words such as small, smaller, smallest.

1. Have students work in cooperative learning groups to ask each other similar questions and record data. Have the group leader report the findings for the group members using the words small, smaller, smallest or equal, greater than and less than.

9. Assign students to specific classes that previous arrangements were made for them to collect data.

10. Comment on reports from students and correct where necessary.

11. Display students' findings in the classrooms from where they were collected. Suggested Student Activities

1. Respond to social skills questions - e.g., listening looks like eye contact, listening sounds like quietness. 
2. Participate in revision.

3. Listen attentively to tasks they are required to complete and ask questions for clarification. Discuss the strategies to be used to collect the data.

4. Individual accountability - each student will relate how they will approach their respondent.

5. Work in cooperative learning groups to collect data on the types of families. Have the group leader report on the findings of the group.

6. Students collect data from a select number of students in other Grade 2 classes.

7. Write the findings using the words, small, smaller, smallest or equal, greater than and less than. Library Activity: Work with the librarian to locate mathematics text with information shown in simple graph format.

Vocabulary: family, living, together, members

The lesson plan shows that the teacher librarian will collaborate with the Grade 2 classroom teachers because the topic is common to all grades 2 classes and the school library curriculum is written to match what is being taught in these grades. This is to provide the required entry point for all teacher librarian and teacher collaborations. It should be noted that cooperative learning was included to provide a learner- centred lesson and to promote interdependence as well as individual accountability. The AASL Standards for the $21^{\text {st }}$ Century Learner was chosen because it fits well with the activities of the lesson. In addition, the first two steps of the Big6 information literacy skills were needed because the teacher librarian and the classroom teacher have to explain the tasks as well as the strategies to collect the data to their students. The social skill of listening was specifically chosen because students were going to be engaged in interviews and needed to learn listening skills. Of note is the mathematics lessons that is embedded in this lesson on using the symbols greater than and less than to make this lesson truly crosscurricular.

\section{CONCLUSION AND IMPLICATIONS}

Based on the findings, the present Grades 1-3 curricular in Jamaica was developed using the cross-curricular approach. However, Grades 4-6 curricular were distinct due to the capacity for integration through research and project works based on interdisciplinary themes. This means that there could be some difficulties with the teacher librarian being able to integrate what is being taught in the classroom with the MILID competencies. The teaching strategies correlated with cooperative learning and multiple intelligences were not evident in the activities section as there was no mention of the elements of cooperative learning or even the types of multiple intelligences. This implies that students were likely to be less engaged with each other and their strongest intelligence was not used to strengthen the weaker ones. The low percentage of MILID topics that was evident would not likely allow students to acquire the knowledge, skills and attitude to function effectively and efficiently in this information environment.

There were also in many instances a small percentage of the AASL Standards for the $21{ }^{\text {st }}$ Century Learner in each curriculum which means that the teacher librarian would have the play the leading role in seeing to it that school library lessons incorporate these standards to help students achieve to adequately achieve a high level of success in these standards. The absence of the Big6 skills were obvious and this has likely resulted in students not being fully information literate as well as not having the requisite skills to complete an assignment or any other task with a high level of satisfaction. The cross curricular approach to the MILID school library curricular will not in any way increase the teaching load of teacher librarians and teachers. It will instead result in better learning outcomes for students in this information age.

\section{RECOMMENDATIONS}

Based on the findings the following recommendations are being made: 
1. The Curriculum Development Unit at the MOEYI should be made aware of MILID, the AASL Standards for the $21^{\text {st }}$ century learner, the Big6 information problem solving skills so that these can be included in the primary school curricular when next they will be revised.

3. The revised curriculum should also include information on how to use the multiple intelligences theory as well as cooperative learning strategy in lessons.

4. The MOEYI grades 4-6 school curricular should also be re-designed to use the cross- curricular approach.

\section{FURTHER RESEARCH}

Similar research should be conducted on the Grades 7-13 curricular. The findings should be used to develop a secondary school library cross-curriculum for these grades.

\section{REFERENCES}

Alvior, M. G. (2014). The meaning and importance of curriculum development. In SimplyEducate. Me. Retrieved Feb. 15, 2017 from http://simplyeducate.me/2014/12/13/themeaning-and-importance-of-curriculum-development/

Association of College and Research Libraries (2000). What is information literacy? Retrieved on December 17, 2016 from http://leddy.uwindsor.ca/node/3498

Barnes, J. (2014). An introduction to cross-curricular learning. Retrieved on Feb. 15, 2017 from https://www.researchgate.net/publication/274313611_An_Introduction_to_CrossCurricular_Learning

Beckmann, A. (2014). A conceptual framework for cross-curricular teaching. Retrieved Feb. 15, 2017 from http://www.sciencemath.ph-gmuend.de/Download/Odense09.pdf

CCSSO/WCER (2004). Designing curriculum units. Retrieved Dec. 27, 2016, from http://www. connectedcalifornia.org/downloads/LL_Designing_Curriculum_Units_2010_v5_web.pdf

ConnectEd (2010). Designing multidisciplinary integrated curriculum units. Retrieved Dec. 23, 2016 from http://www.connectedcalifornia.org/downloads/ LL_Designing_Curriculum_Units_2010_v5_web.pdf

Darling-Hammond, L. (2010). Performance counts: Assessment systems that support highquality learning. Washington, DC: Council of Chief State School Officers.

Edutopia (2016). Multiple intelligences: What the research says. Retrieved Apr. 30, 2017 from https://www.edutopia.org/multiple-intelligences-research

Eisenberg, M., \& Berkowitz, B. Big6 overview. (2017). Retrieved May 4, 2017, from http://big6.com/pages/about/big6-skills-overview.php

HMLe Improvement Scottish Education (2007). Making effective use of curriculum flexibility in primary schools: Improving Scottish education. Retrieved Dec. 12, 2016 from http://dera.ioe.ac.uk/6933/1/cfps\%20amended.pdf

Krippendorff, K. (2013). Content analysis: An introduction to its methodology ( $3^{\text {rd }}$ ed.). London, UK: SAGE.

Nikolov, R., Shoikova, E., \& Kovatcheva, E. (2014). Competence based framework for curriculum development. Retrieved Dec. 18, 2016 from https://unesco.unibit.bg/sites/default/files/CBFramework_TEMPUSPICTET_Nikolov_Shoikova_Kovatcheva.pdf

Partnership for the 21st Century Skills (n.d.). Retrieved Feb. 20, 2017 from http://www.p21.org/storage/documents/p21-stateimp_standards

Price, A. (2010). What are the benefits for teaching and learning of cross-curricular work using thinking skills, techniques and language? Retrieved Dec. 22, 2016 from http://www.ntrp.org.uk/sites/all/documents/A.\%20Price\%20FINAL.pdf

UNESCO (n.d.) Media and information literacy. Retrieved from http://www.unesco.org/new/en/communication-and-information/media- 
development/media-literacy/mil-as-composite-concept/

Webber, S. (2010). Eight questions educators should ask about curriculum. Retrieved Dec.

23, 2016 from http://edge.ascd.org/blogpost/eight-questions-educators-should-ask-aboutcurriculum

What is interdisciplinary cross-curricular teaching? (n.d.). Retrieved Dec.23, 2016 from https://www.eduplace.com/rdg/res/literacy/interd0.html

Why use cooperative learning? (n.d.). Retrieved Dec. 20, 2016, from http://serc.carleton.edu/introgeo/cooperative/whyuse.html

Wilson, C. (2012). Media and information literacy: Pedagogy and possibilities. In Comunicar Scientific Journal 3 of Media Education. Curriculum and Teacher Training in Media Literacy, $39(20), 15-22$. 